\title{
Влияние топологии элементов резонатора волоконного F8 лазера на свойства импульсной генерации
}

\author{
С.А. Хрипунов, А.Ю. Кохановский", А.В. Иваненко, \\ М.Д. Гервазиев, С.В. Смирнов, С.М. Кобцев \\ Новосибирский государственный университет \\ *E-mail: alexey.kokhanovskiy@gmail.com
}

DOI:10.31868/RFL2018.142-143

Волоконные лазеры с использованием петлевых усиливающих зеркал и резонаторов в виде “восьмёрки” (F8 лазеры) широко применяются для получения стабильного режима синхронизации мод излучения и генерации импульсов с относительно высокой энергией, в том числе рекордно высокой [1] для задающих генераторов. Использование в F8 лазерах двух активных сред существенно расширяет их функциональные возможности [2, 3]. На данный момент существует два подхода к конфигурированию резонаторов F8 лазеров расположение двух активных сред в одной петле резонатора [1-3] или расположение активных сред в разных петлях резонатора [4].

Данная работа посвящена исследованию влияния топологии элементов резонатора F8 лазера на свойства импульсной генерации в режиме синхронизации мод излучения.

\section{Экспериментальная установка}

Схемы лазерных резонаторов с разной топологией элементов представлены на Рис.1:
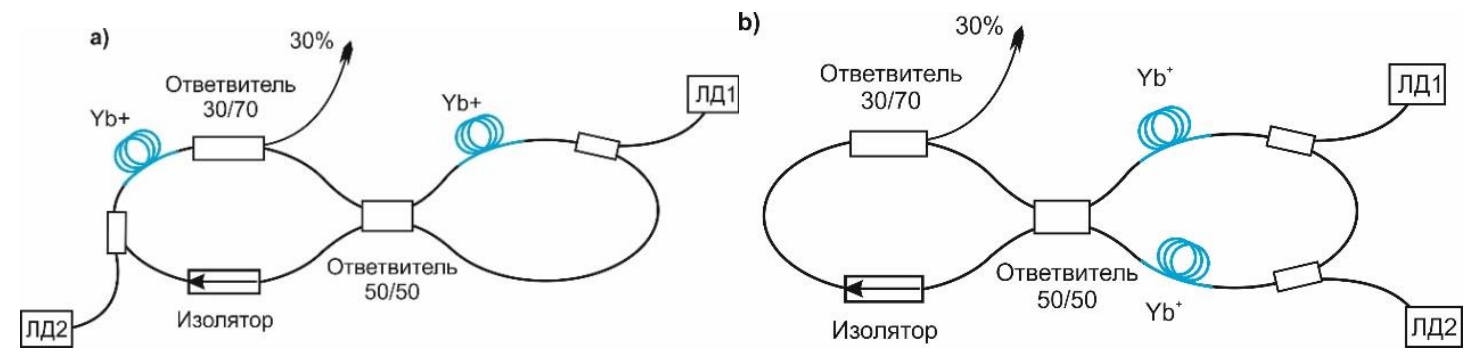

Рис. 1. Схемы лазерных резонаторов в виде восьмерки а) усиливающие волокна в двух петлях лазерного резонатора b) усиливающие волокна в одной петле лазерного резонатора

Схема а) состоит из двух волоконных петель соединенных волоконным ответвителем с коэффициентом деления 50/50. Правая петля представляет собой классическое нелинейное усиливающее петлевое зеркало с активным волокном, легированным иттербием. Левая петля содержит изолятор для обеспечения однонаправленности излучения, усиливающее волокно, легированное иттербием и ответвитель 30/70, выводящий $30 \%$ излучения из лазерного резонатора. Для корректного сравнения двух лазерных конфигурации вторая лазерная схема была получена из первой перемещением усиливающего участка из одной петли во вторую. Таким образом, обе схемы были реализованы на основе идентичных волоконных компонент. Сохранение длин волоконных петель лазерного резонатора обеспечивалось замещением активных волокон пассивными участками волокна той же длины. Частота повторения импульсов составляла 14.87 МГц для схемы а) и 15.17 МГц для схемы b).

Результаты 
Для измерения параметров импульсных режимов использовалась система автоматического измерения длительности автокорреляционной функции, частоты повторения и средней мощности импульсного излучения. На основе этих данных была построена карта пиковой мощности выходного излучения в зависимости от токов диодов накачки активных волокон (Рис.2.):
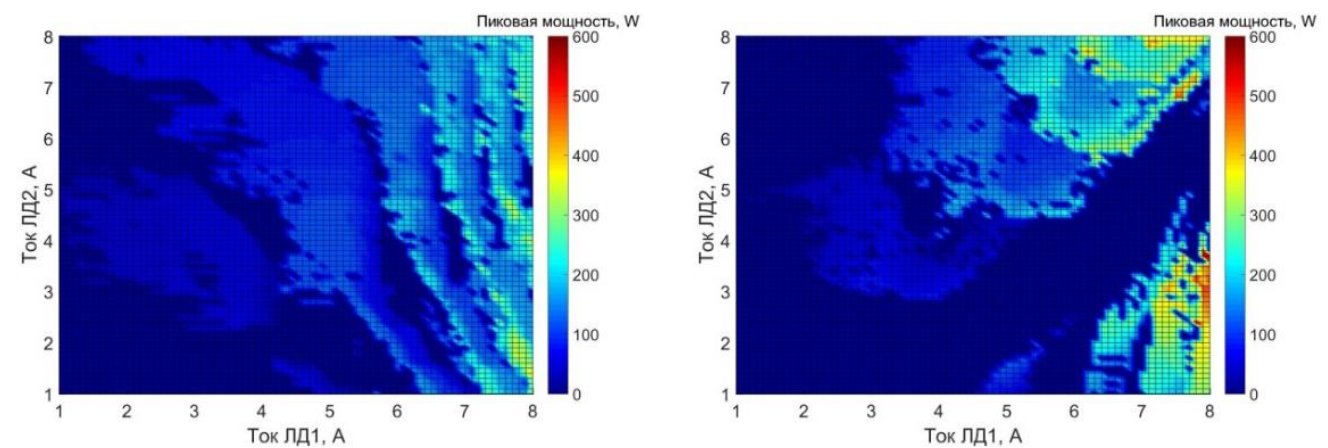

Рис. 2. Пиковая мощность выходных импульсов в зависимости от токов лазерных диодов накачки

Согласно Рис.2. схема b) позволяет достичь больших пиковых мощностей выходных импульсов. Это подтверждает эффективность генерации второй гармоники, полученной с помощью автокоррелятора (Рис.3.). Отношение максимальных пиковых мощностей импульсного излучения схемы b) к схеме а) составило 2.2 .
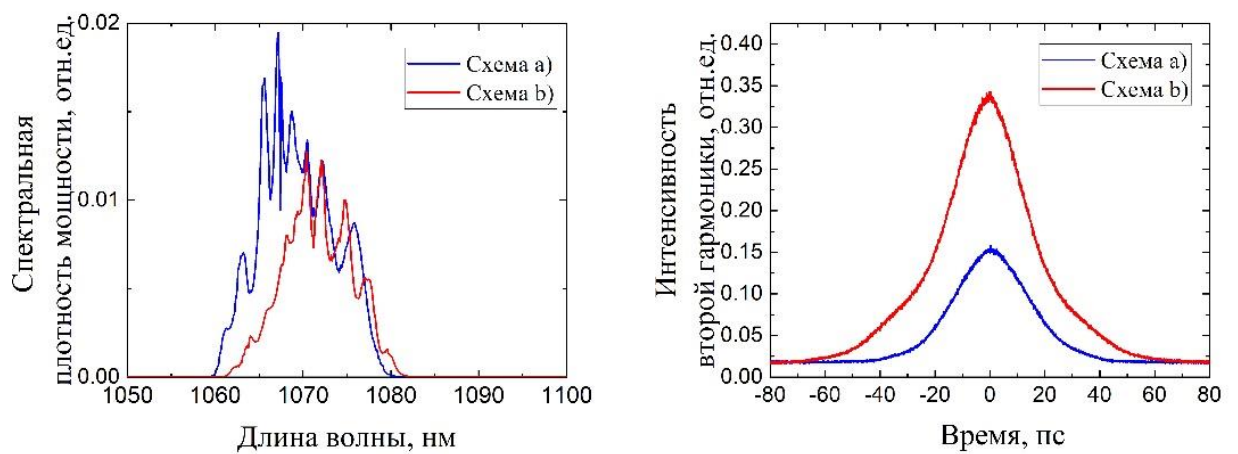

Рис. 3. Оптический спектр и автокорреляционная функция импульсов с максимальной пиковой

\section{Заключение}

мощностью двух схем лазерного резонатора

В работе представлены карты режимов импульсной генерации в волоконных лазерных резонаторах в виде восьмерки с разной топологией элементов. Добавление второго усиливающего участка позволяет эффективно варьировать пиковую мощность импульсов. Схема с двумя усиливающими волокнами в одной петле резонатора позволяет добиться пиковой мощности в 2.2 раз больше по сравнению со схемой с двумя усиливающими волокнами в двух петлях резонатора.

Данная работа поддержана грантом РФФИ 18-32-00560

\section{Литература}

[1] A. Ivanenko, S. Kobtsev, S. Smirnov, and A. Kemmer, Opt. Express 24, 6650 (2016)

[2] S. Kobtsev, A. Ivanenko, and A. Kokhanovskiy, (2018)

[3] S.Smirnov, et al, Optics Letters, v. 42, Issue 9, pp. 1732-1735 (2017)

[4] M. Erkintalo, et al, Opt. Express 20, 22669 (2012) 